Check for updates

The BMJ

kabbasi@bmi.com Follow Kamran on Twitter@KamranAbbasi Cite this as: BMJ2020;371:m4487 http://dx.doi.org/10.1136/bmj.m4487 Published: 19 November 2020

\title{
Covid-19: Screening without scrutiny, spending taxpayers' billions
}

\section{Kamran Abbasi executive editor}

Mass testing is a euphemism for population screening. A range of experts who care about screening for the right reasons, in the right contexts, with the right tests, and with the correct follow-up, are in no doubt.

Mike Gill and Muir Gray (who was knighted for his work on national screening programmes) insist the Liverpool mass testing pilot must be stopped. ${ }^{1}$ It is screening by the back door, bypassing appraisal by the UK's National Screening Committee. The lateral flow test being used is of doubtful value, with a high false negative rate. Although the false positive rate is small it is still a problem in a low prevalence setting.

Angela Raffle, another leading expert on screening, argues that Operation Moonshot takes us back to the paternalistic 1960 s, ignores data protection and privacy laws, and is potentially in breach of the Declaration of Helsinki. ${ }^{23}$ Bing Jones and colleagues say we must stop being polite about "test and trace," with its narrow focus on testing, costing billions of pounds to the taxpayer. ${ }^{4}$

Instead of listening, inviting scrutiny, or waiting for the results of its Liverpool pilot, England's Department of Health and Social Care is rushing out mass testing to 67 more areas. ${ }^{5}$ The government is using the covid-19 pandemic to cut corners in procurement and award contracts without transparency, finds the National Audit Office, which reviewed $€ 18$ bn of contracts awarded in the first wave. ${ }^{6}$ Companies are being prioritised solely on the recommendation of officials and politicians. An emergency is no excuse for this bad practice, and the Public Accounts Committee says the NAO's findings are likely to be the tip of the iceberg.

Some might say The $B M J$ is playing politics, as one reader does. ${ }^{7}$ But The BMJ's duty is to patients and the public, especially the most vulnerable, ${ }^{8}$ and not to any political party or any company's shareholders. It is inevitable that whichever party is in power is held to account. Stephen Armstrong's BMJ investigation into the recent award of a $€ 75 \mathrm{~m}$ contract for an antibody test that works less well than claimed, even for surveillance purposes, shows why that scrutiny is essential..$^{-11}$ The government's pandemic response is suppressing science for political and financial gain. ${ }^{12}$

To echo Stephen Sondheim, "You take one road, you try one door, there isn't time for any more."13 That road may lead to a vaccine. ${ }^{1415}$ But the road is muddier than it needed to be, steeper and more tortuous, and littered with premature deaths and long covid. The government is now embarking on a £1oobn mass testing programme that the experts say is fatally flawed, founded on inadequate diagnostic tests, not backed up by adequate contact tracing and isolation, with a track record of maladministration. Among these failures, perhaps the gravest error is an arrogant disregard for scrutiny.

Gill M, Gray M. Mass testing for covid-19 in the UK. BMJ2020;371:m4436. doi: 10.1136/bmj.m4436 pmid: 33199289

2 lacobucci G, Coombes R. Covid-19: Government plans to spend $£ 100 \mathrm{bn}$ on expanding testing to 10 million a day. BMJ2020;370:m3520. doi: 10.1136/bmi.m3520 pmid: 32907851

3 Raffle AE. Screening the healthy population for covid-19 is of unknown value, but is being introduced nationwide. BM/2020;371:m4438.

4 Jones B, Czauderna J, Redgrave P. We must stop being polite about Test and Trace-there comes a point where it becomes culpable. BMJ Opinion. 10 Nov 2020. https://blogs.bmj.com/bmi/2020/11/10/we-must-stop-being polite-about-test-and-trace-there-comes-a-point-where-it-becomes-culpable.

5 lacobucci G. Covid-19: Government ramps up "Moonshot" mass testing. BMJ 2020;371:m4460doi: 10.1136/bmj.m4460

6 lacobucci G. Covid-19: Government has spent billions on contracts with little transparency, watchdog says. BMJ 2020;371:m4474doi: 10.1136/bmj.m4474.

7 Powell DEB. The BMJ's political stance-where is the balance?BMJ 2020;371:m4391doi: 10.1136/bmi.m4391.

8 Mathew R. Rammya Mathew: Reshaping healthcare for vulnerable people. BMJ 2020;371:m4426doi: 10.1136/bmj.m4426 .

9 Armstrong S. Testing times for the government's favoured antibody kit. BM/2020;371:m4440. doi: 10.1136/bmi.m4440 pmid: 33199381

10 Mulchandani R, Jones HE, Taylor-Phillips S, etalEDSAB-HOME and COMPARE Investigators. Accuracy of UK Rapid Test Consortium (UK-RTC) "AbC-19 Rapid Test" for detection of previous SARS-CoV-2 infection in key workers: test accuracy study. BMJ 2020;371:m4262.pmid: 33177070

11 Gill D, Ponsford MJ. Testing for antibodies to SARS-CoV-2. BMJ 2020;371:m4288doi: 10.1136/bmi.m4288

12 Abbasi K. Covid-19: politicisation, "corruption," and suppression of science BMJ2020;371:m4425. doi: 10.1136/bmi.m4425 pmid: 33187972

13 Oliver D. David Oliver: The roads not taken in our covid response. BM] 2020;371:m4434doi: 10.1136/bmi.m4434.

14 Mahase E. Covid-19: Moderna vaccine is nearly 95\% effective, trial involving high risk and elderly people shows. BMJ 2020;371:m4471doi: 10.1136/bmi.m4471 .

15 Salisbury H. Helen Salisbury: Managing vaccine expectations. BM 2020;371:m4448doi: 10.1136/bmj.m4448 